\title{
Listeria monocytogenes in Faeces from Clinically Healthy Dairy Cows in Sweden
}

\author{
By H. Unnerstad, A. Romell, H. Ericsson, M.-L. Danielsson-Tham and W. Tham
}

Department of Food Hygiene, Faculty of Veterinary Medicine, Swedish University of Agricultural Sciences, Uppsala, Sweden.

\begin{abstract}
Unnerstad H, Romell A, Ericsson H, Danielsson-Tham M-L, Tham W: Listeria monocytogenes in faeces from clinically healthy dairy cows in Sweden. Acta vet. scand. 2000, 41, 167-171. - Faecal samples from 102 clinically healthy dairy cows, representing 34 farms in the Swedish province of Uppsala, were analysed for the presence of Listeria spp. using an enrichment procedure. Listeria monocytogenes was isolated from six $(6 \%)$ and $L$. innocua from $2(2 \%)$ cows. From each of the 6 samples positive for $L$. monocytogenes, 5 isolates were further characterised by restriction enzyme analysis using the 3 enzymes Apa I, Sma I, and Asc I, followed by pulsed-field gel electrophoresis. Three of the L. monocytogenes positive cows lived at the same farm, and they all harboured the same clonal type. One of these 3 cows also harboured a further clonal type of $L$. monocytogenes. The fact that one of the cows harboured 2 different clonal types of L. monocytogenes is important from an epidemiological point of view when routes of infection are to be investigated.
\end{abstract}

Listeria monocytogenes; cow; faecal samples; frequency of carriers; clonal type; restriction enzyme; pulsed-field gel electrophoresis.

\section{Introduction}

Listeria monocytogenes is a Gram positive rod that can infect both humans and animals with severe consequenses such as abortion, septicaemia, and involvement of the CNS (Seeliger \& Jones 1986). The pathogen may be present in a wide range of food (Farber \& Peterkin 1991) as well as in certain forage products (Hird \& Genigeorgis 1990), some of which are considered important sources of listeriosis. Animals and humans may also be clinically healthy carriers of the bacterium (Husu 1990, Schönberg \& Gerigk 1991).

The aim of this study was to investigate the frequency of clinically healthy carriers of $L$. monocytogenes among dairy cows in the province of Uppsala, Sweden, and to characterise the isolates obtained by use of restriction enzyme analysis (REA) with PFGE.

\section{Materials and methods}

Faecal samples

This study included 34 randomly selected farms in the province of Uppsala, Sweden. Three clinically healthy cows were sampled on each farm, for a total of 102 cows. From each cow, a handful of faeces was collected directly from the rectum, by use of a plastic rectal glove, and put into a sterile plastic vial. The samples were kept at $4^{\circ} \mathrm{C}$ until analysis.

\section{Listeria isolation and confirmation}

The Listeria analyses were carried out mainly according to the procedure described by the International Dairy Federation (1990). The method can briefly be described as follows: 25 $\mathrm{g}$ faeces from each sample was transfered into $225 \mathrm{ml}$ Listeria Enrichment Broth (Oxoid, Basingstoke, Hampshire, England and Difco, De- 
Table 1. REA profiles of $30 \mathrm{~L}$. monocytogenes strains isolated from 6 cows.

\begin{tabular}{lcccccc}
\hline & & & \multicolumn{2}{c}{ Restriction enzyme profiles } & \\
\cline { 3 - 5 } Strain designation & Cow & Farm & Apa I & Sma I & Asc I & Clonal type \\
\hline SLU 408-412 & 1 & 1 & A & B & C:1 & I A \\
SLU 413-417 & 2 & 1 & A & B & C:1 & I A \\
SLU 418-421 & 3 & 1 & A & B & C:1 & I A \\
SLU 422 & 3 & 1 & D & E & F & II \\
SLU 423-427 & 4 & 2 & G & H & I & III \\
SLU 428-432 & 5 & 3 & A & B & C:2 & I B \\
SLU 433-437 & 6 & 4 & A & B & J & IV \\
\hline
\end{tabular}

troit, MI, USA) supplemented with acriflavine, nalidixic acid, and cycloheximide in accordance with the IDF Standard 143:1990. The broth was incubated at $30^{\circ} \mathrm{C}$ for $48 \mathrm{~h}$. The $\mathrm{pH}$ of the incubated enrichment broth was measured with a $\mathrm{pH}$ meter after $48 \mathrm{~h}$ (Orion Research model 701, Cambridge, MA, USA) to ensure that the $\mathrm{pH}$ was not too low for L. monocytogenes growth. Then, $0.1 \mathrm{ml}$ of the enrichment broth was spread with a glass spatula onto an Oxford agar plate (Oxoid). The agar plates were incubated at $37^{\circ} \mathrm{C}$ and examined after $24 \mathrm{~h}$ and $48 \mathrm{~h}$. When typical Listeria colonies had grown, 5 colonies from each plate were isolated, subcultured on horse blood agar, and confirmed. Bacterial cells were tested for Gram reaction, cell shape, haemolytic reaction on horse blood agar, tumbling motility at $20^{\circ} \mathrm{C}$, fermentation of mannitol, ramnose and xylose, production of catalase, and hydrolysis of esculine (Seeliger \& Jones 1986). All L. monocytogenes isolates were serotyped with Listeria $\mathrm{O}$ Antiserum type 1 and 4 (Difco Laboratories, Detroit, MI, USA). Two L. monocytogenes isolates out of the 5 from each positive cow (including strain 422 , Table 1) were further serotyped according to reference method (Seeliger \& Höhne 1979). All L. monocytogenes isolates were frozen in $80 \%$ Brain Heart Infusion Broth (Merck, Darmstadt, Germany) and 20\% glyce$\mathrm{rol}$, vol $/ \mathrm{vol},-70^{\circ} \mathrm{C}$, for further, later, characterisation.
Preparation of gel plugs for PFGE

The procedure described is based on the method of Brosch et al. (1991) and the Pharmacia LKB Biotechnology protocol for preparing Escherichia coli DNA (Pharmacia). One loopful of each freeze-stored bacterial culture was streaked onto horse blood agar and incubated at $37^{\circ} \mathrm{C}$ for $24 \mathrm{~h}$. One well-isolated colony was inoculated into $10 \mathrm{ml}$ Brain Heart Infusion Broth (Difco) in a centrifuge tube and incubated at $37^{\circ} \mathrm{C}$ for $18-24 \mathrm{~h}$. The tube was then centrifuged $\left(10 \mathrm{~min}, 310 \mathrm{~g}, 4^{\circ} \mathrm{C}\right)$; the pellet was washed once with $10 \mathrm{ml}$ Pett IV (10 mM Tris $\mathrm{HCl}, \mathrm{pH} 7.6,1 \mathrm{M} \mathrm{NaCl}$ ), centrifuged again, and then resuspended in $2.4 \mathrm{ml}$ Pett IV. Of the bacterial suspension, $500 \mu \mathrm{l}$ was heated to $40^{\circ} \mathrm{C}$ and mixed with $500 \mu \mathrm{l}$ of $1 \%$ low-melt agarose solution (InCert Agarose, FMC BioProducts, Rockland, ME, USA) of the same temperature. The mixture was distributed into insert moulds (110 $\mu$ in each mould) and then cooled for 30 $\min$ at $4{ }^{\circ} \mathrm{C}$. The gel plugs were incubated overnight at $37^{\circ} \mathrm{C}$ in a solution of $3 \mathrm{mg}$ lysozyme (Boehringer Mannheim GmbH, Mannheim, Germany) per ml $0.1 \mathrm{M}$ phosphate buffer ( $\mathrm{pH}$ 7.0 , with $20 \%$ sucrose); washed $5 \mathrm{~min}$ in TEbuffer and incubated in $0.5 \mathrm{M}$ EDTA, $1 \% \mathrm{~N}$ lauroyl-sarcosine (Sigma, St Louis, MO, USA) with $2 \mathrm{mg} / \mathrm{ml}$ Pronase E (Boehringer Mannheim); and incubated at $55^{\circ} \mathrm{C}$ for $48 \mathrm{~h}$ with the solution changed after $24 \mathrm{~h}$. The plugs were sliced in longitudinal halves (about $50 \mu$ leach) 
and washed in TE-buffer (10 mM Tris, $1 \mathrm{mM}$ EDTA, $\mathrm{pH}$ 8.0). Pronase $\mathrm{E}$ was deactivated with $350 \mu$ g Pefabloc ${ }^{\circledR} \mathrm{SC}$ (Boehringer Mannheim) per $\mathrm{ml} \mathrm{TE}$-buffer for $2 \mathrm{~h}$ at $50^{\circ} \mathrm{C}$ and, finally, the plugs were washed again in TE-buffer.

\section{Restriction enzyme cleavage and PFGE}

The restriction enzymes Apa I, Sma I (10 u/ $\mu$, Boehringer Mannheim) and $A s c \mathrm{I}(10 \mathrm{u} / \mu \mathrm{l}$, New England Biolabs, Beverly, MA, USA) were used as recommended by the manufacturers. For Apa I and Sma I, half a gel plug $\left(10^{8}\right.$ bacteria) was incubated overnight at $30^{\circ} \mathrm{C}$ and $25^{\circ} \mathrm{C}$, respectively, in $25 \mathrm{u}$ enzyme, $11.5 \mu \mathrm{g}$ acetylated BSA (bovine serum albumin; Promega, Madison, WI, USA), $11.5 \mu$ l Buffer A (incubation buffer for restriction enzymes, $10 \times$ conc., Boehringer Mannheim), and sterile water up to $115 \mu \mathrm{l}$. For $A s c$ I half a gel plug was incubated overnight in $14 \mathrm{u}$ enzyme, $11.5 \mu \mathrm{g}$ acetylated BSA, $12.6 \mu \mathrm{l}$ NE Buffer $4(10 \times$ conc., New England Biolabs), and sterile water up to $115 \mu \mathrm{l}$ at $37^{\circ} \mathrm{C}$. Plugs with Escherichia coli (G5244) cleaved with $\mathrm{Xba}$ I were used as markers. The plugs were cast in a $1.4 \%$ Fastlane Agarose gel (FMC BioProducts, Rockland, ME, USA) and run in a Pharmacia Gene Navigator (Pharmacia, Uppsala, Sweden) at $9^{\circ} \mathrm{C}$ with circulating $0.5 \times$ TBE-buffer ( $45 \mathrm{mM}$ Tris-borate, $1 \mathrm{mM}$ EDTA). The running programme consisted of continously interpolated pulses from 4 to $40 \mathrm{~s}$ during $24 \mathrm{~h}$ under a voltage of $200 \mathrm{~V}$. The gel was stained in ethidium bromide solution (final concentration $0.75 \mu \mathrm{g} / \mathrm{ml}$ ) for $20 \mathrm{~min}$, washed for $20 \mathrm{~min}$ in $0.5 \times$ TBE-buffer and photographed over a $312 \mathrm{~nm}$ transilluminator. The lanes on the gel were visually examined. DNA was prepared twice from each strain and analysed by PFGE to ensure repeatability.

\section{Results}

The $\mathrm{pH}$ of the enrichment broth after $48 \mathrm{~h}$ incubation averaged 6.0 (range: 5.6-6.3). Listeria

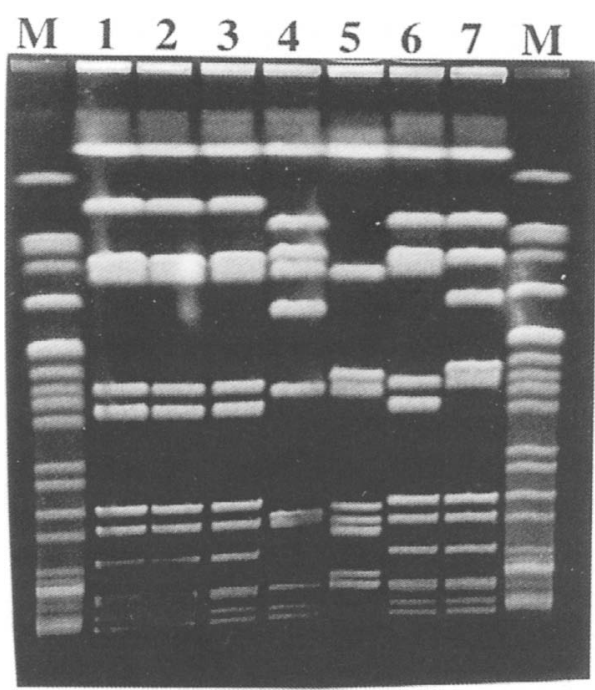

Figure 1. REA profiles of L. monocytogenes strains from faeces of clinically healthy dairy cattle. The DNA is cleaved with Asc I. M, E. coli (G5244) cleaved with $X b a$ I used as marker; lane 1, strain SLU 409 profile C:1; lane 2, strain SLU 414 profile C:1; lane 3, strain SLU 418 profile C:1; lane 4, strain SLU 422 profile F; lane 5, strain SLU 424 profile I; lane 6, strain SLU 429 profile C:2; lane 7, strain SLU 434 profile J; M, E. coli (G5244) cleaved with Xba I.

spp. were isolated from faecal samples from 8 out of the $102(8 \%)$ clinically healthy dairy cows. Six of the cows harboured L. monocytogenes (6\%) and 2 cows $L$. innocua ( $2 \%)$; the $L$. innocua strains were not further investigated. Three of the L. monocytogenes positive cows lived at the same farm (farm 1); the others were located at different farms. Altogether 6 cows rendered $30(6 \times 5)$ isolates of $L$. monocytogenes. All the isolated L. monocytogenes strains belonged to serogroup $1 / 2$. Two strains from each positive cow (altogether 12 strains) were further serotyped according to reference method (Seeliger \& Höhne 1979), and all these strains belonged to serovar $1 / 2 \mathrm{a}$. The 30 isolated $L$. monocytogenes strains were characterised by pulsed-field gel electrophoresis (Fig. 1, 
Table 1). The strains could be grouped into 5 clonal types according to their restriction enzyme profiles. The $3 \mathrm{~L}$. monocytogenes positive cows from the same farm (cows no. 1, 2, and 3) harboured strains with indistinguishable restriction profiles with all 3 enzymes (clonal type I A). In addition, cow no. 3 also harboured another clonal type of $L$. monocytogenes with clearly different profiles with all 3 enzymes (clonal type II). The isolates from the other 3 cows from farms 2, 3, and 4 showed difference in restriction profile with at least one enzyme (clonal types III, I B, and IV).

The results of the second DNA preparation and PFGE analysis were identical with the results of the first.

\section{Discussion}

The isolation of $L$. monocytogenes from faeces from $6 \%$ of the dairy cows is well in line with the results of Husu (1990) who isolated $L$. monocytogenes from faeces from $6.7 \%$ of 3,878 randomly selected dairy cows representing 249 farms in Finland during 2 years. The shedding of L. monocytogenes from clinically healthy cows shows that cattle faeces could be a source of contamination of milk and carcasses with L. monocytogenes, and thus may contribute to foodborne listeriosis. Other studies have shown that food products can be contaminated with $L$. monocytogenes in the processing industry (Boerlin \& Pifaretti 1991, Rørvik et al. 1995, Unnerstad et al. 1996, Ericsson et al. 1997).

The 3 L. monocytogenes positive cows that lived at the same farm all harboured clonal type I A of L. monocytogenes. This is not surprising because these cows lived in the same environment and consumed the same forage. However, one of the 3 cows (no. 3), also harboured another clonal type, no. II. The profiles of that strain (SLU 422) were completely different with all 3 enzymes and may be considered un- related to clonal type I A. A human faecal carrier excreting 2 different serovars of $L$. monocytogenes has been reported (MacGowan et al. 1991). More than one clonal type of $L$. monocytogenes have also been found in brain tissue of a fallow deer (Tham et al. 1999) as well as in a soft cheese (Danielsson-Tham et al. 1993). The fact that there may be more than one clonal type of $L$. monocytogenes present in the same sample is essential. In a case, or outbreak, of listeriosis, it is urgent to trace the origin of infection in order to inhibit further spreading. The conceivable presence of several clonal types makes it interesting to characterise several isolates from both the patients and the suspected food or forage items in order to maximize the possibility of establishing an epidemiological link.

In the present study, clonal type I B had restriction profiles that were indistinguishable from clonal type I A with 2 enzymes, but differed with a single genetic event (Tenover et al. 1995) with the enzyme Asc I (Table 1). Hence, the isolates from cow no. 5 may be considered closely related to clonal type I A, based on the restriction profiles. However, since a link is not firmly established, the epidemiological relationship is uncertain.

\section{Acknowledgements}

This study was supported financially by Stadsveterinär Billströms Foundation, to which we express our gratitude. The Department of Ambulant Service, Faculty of Veterinary Medicine, Swedish University of Agricultural Sciences is gratefully acknowledged for collecting the faecal samples, and Prof. J. Bille and Dr. E. Bannerman, Medical Bacteriology Laboratory, University Hospital, Lausanne, Switzerland for serotyping 12 of the strains.

\section{References}

Boerlin P, Piffaretti J-C: Typing of human, animal, food, and environmental isolates of Listeria monocytogenes by multilocus enzyme electrophoresis. Appl. Environ. Microbiol. 1991, 57, 1624-1629.

Brosch R, Buchrieser C, Rocourt J: Subtyping of Lis- 
teria monocytogenes serovar $4 \mathrm{~b}$ by use of lowfrequency-cleavage restriction endonucleases and pulsed-field gel electrophoresis. Res. Microbiol. 1991, 142, 667-675.

Danielsson-Tham M-L, Bille J, Brosch R, Buchrieser $C$, Persson K, Rocourt J, Schwarzkopf A, Tham W, Ursing J: Characterization of Listeria strains isolated from soft cheese. Int. J. Food Microbiol. 1993, 18, 161-166.

Ericsson H, Eklöw A, Danielsson-Tham M-L, Loncarevic $S$, Mentzing $L-O$, Persson $I$, Unnerstad $H$, Tham $W$ : An outbreak of listeriosis suspected to have been caused by rainbow trout. J. Clin. Microbiol. 1997, 35, 2904-2907.

Farber JM, Peterkin PI: Listeria monocytogenes, a Food-Borne Pathogen. Microbiol. Reviews. 1991, 55, 476-511.

Hird DW, Genigeorgis C: Listeriosis in food animals: clinical signs and livestock as a potential source of direct (nonfoodborne) infection for humans. In: Miller AL, Smith JL and Somkuti G A (eds.): Foodborne Listeriosis., Elsevier Science Publishers B. V., Amsterdam, 1990, 31-39.

Husu JR: Epidemiological studies on the occurence of Listeria monocytogenes in the feces of dairy cattle. J. Vet. Med. 1990, B37, 276-282.

International Dairy Federation: International Provisional IDF Standard 143:1990. Detection of Listeria monocytogenes. IDF, Square Vergote 41, B-1040 Brussels, Belgium, 1990.

MacGowan AP, Marshall RJ, MacKay IM, Reeves $D S$ : Listerial faecal carriage by renal transplant recipients, haemodialysis patients and patients in general practice: its relation to season, drug therapy, foreign travel, animal exposure and diet. Epidemiol. Infect. 1991, 106, 157-166.

Pharmacia LKB Biotechnology; Preparation of E. coli DNA. Protocol No. 18-1026-33. Uppsala, Sweden.

Rørvik LM, Caugant DA, Yndestad M: Contamination pattern of Listeria monocytogenes and other Listeria spp. in a salmon slaughterhouse and smoked salmon processing plant. Int. J. Food Microbiol. 1995, 25, 19-27.
Schönberg A, Gerigk K: Listeria in effluents from the food-processing industry. Rev. Sci. Tech. Off. Int. Epiz. 1991, 10, 787-797.

Seeliger HPR, Höhne K: Serotyping of Listeria monocytogenes and Related Species. In: Bergan $\mathrm{T}$ and Norris $\mathrm{J}$ (eds.): Methods in Microbiology. Academic Press, New York, 1979, 31-49.

Seeliger HPR, Jones D: Genus Listeria. In: Sneath PHA, Mair NS, Sharpe ME and Holt JG (eds.): Bergey's Manual of Systematic Bacteriology. vol. 2, Williams \&Wilkins, Baltimore, USA, 1986, 1235-1245.

Tenover FC, Arbeit RD, Goering RV, Mickelsen PA, Murray BE, Persing DH, Swaminathan B: Interpreting chromosomal DNA restriction patterns produced by pulsed-field gel electrophoresis: criteria for bacterial strain typing. J. Clin. Microbiol. 1995, 33, 2233-2239.

Tham W, Bannerman E, Bille J, Danielsson-Tham M$L$, Eld K, Ericsson H, Gavier-Widén D, Rocourt J, Mörner T: Listeria monocytogenes subtypes associated with mortality among fallow deer (Dama dama). J. Zoo \& Wildlife Med. 1999, 30, 545-549.

Unnerstad H, Bannerman E, Bille J, DanielssonTham M-L, Waak E, Tham W: Prolonged contamination of a dairy with Listeria monocytogenes. Neth. Milk \& Dairy Journal 1996, 50, 493-499.

\section{Sammanfattning}

Listeria monocytogenes $i$ träckprover från kliniskt friska mjölkkor

Träckprover från 102 kliniskt friska kor i Uppsala kommun analyserades med avseende på förekomst av Listeria spp. Listeria monocytogenes isolerades från sex och L. innocua från 2 kor. Från varje L. monocytogenes-positivt prov karakteriserades 5 isolat genom restriktionsenzymklyvning med enzymerna Apa I, Sma I och Asc I följt av pulsfältsgelelektrofores. Samma klontyp av L. monocytogenes isolerades från 3 kor från samma gård. Från en av dessa kor isolerades dessutom ytterligare en klontyp.

(Received November 16, 1999; accepted February 11, 2000).

Reprints may be obtained from: H. Unnerstad, Department of Food Hygiene, Faculty of Veterinary Medicine, Swedish University of Agricultural Sciences, P.O. Box 7009, S-750 07 Uppsala, Sweden. E-mail: helle.unnerstad@Imhyg.slu.se, tel: +46(0) 18-67 23 93, fax: +46 (0) 18-67 2393. 